\title{
Effect of Financial Information and Corporate Social Responsibility Disclosure on Investment Decision: Evidence from an Experimental Study
}

\author{
Hijroh Rokhayati*, Ertambang Nahartyo and Haryono
}

\begin{abstract}
Manuscript type: Research paper

Research aims: This research is based on an experiment which is conducted to examine the effects of financial information and corporate social responsibility (CSR) disclosure on investment decision.

Design/Methodology/Approach: The research employs the laboratory experiment design which involves 45 graduate students as subjects. The independent variable, financial information, is manipulated by favourable and unfavourable financial information while the CSR disclosure is manipulated by prevention focus and promotion focus. The dependent variable, investment decision, is manipulated by using the 10-point Likert scale. Subjects are randomly assigned to one of four treatments (favourable or unfavourable financial information and promotion focus or prevention focus of CSR disclosure).

Research findings: The results show that CSR disclosure affects investment decision. The results also show that subjects decide on
\end{abstract}

\footnotetext{
* Corresponding author: Hijroh Rokhayati is a Lecturer at the Faculty of Economics and Business, Universitas Jenderal Soedirman, Purwokerto, Indonesia. Email: hijroh.rokhayati@ unsoed.ac.id, hijroh.akt@gmail.com

Ertambang Nahartyo is a Lecturer at the Faculty of Economics and Business, Universitas Gadjah Mada, Yogyakarta, Indonesia. Email: ertambang@ugm.ac.id

Haryono is a Lecturer and at the Faculty of Economics and Business, Universitas Gadjah Mada, Yogyakarta, Indonesia. Email: haryono@ugm.ac.id
}

Acknowledgement: The authors wish to thank the Faculty of Economics and Business, Universitas Gadjah Mada for generous funding.

https://doi.org/10.22452/ajba.vol12no1.5 
greater investments when the CSR disclosure is with a prevention focus.

Theoretical contribution/Originality: By investigating the effect of financial information and CSR disclosure on investment decision, this research has effectively used the CSR disclosure strategy to determine investment decision. This research contributes to extant literature by highlighting that CSR disclosure based on regulatory focus can be more effective for investment decision, especially when it has a prevention focus. This persuades investors to make their investment decision.

Practitioner/Policy implication: The findings of the current research show that investors make greater investments in financial information and CSR disclosure with a prevention focus. The findings of this research will encourage firms to disclose their CSR activities by taking into consideration the situational aspects, based on the prevention focus that emphasises on avoiding social and environmental negative effects.

Research limitation/Implications: This research only examines the situational focus of regulation on investment decision. Future research can examine the effect of chronic regulatory focus on investors.

Keywords: Financial Information, Corporate Social Responsibility, Regulatory Focus Theory, Experimental Design, Investment Decision JEL Classification: M41

\section{Introduction}

Corporate social responsibility (CSR) has been widely studied by researchers (McWilliams \& Siegel, 2001) due to its prevalence in the corporate world. Companies practise CSR voluntarily, as a form of compliance with social obligations that go beyond the legal requirements (McWilliams \& Siegel, 2001). The expanding demand of CSR has resulted in many companies reporting their voluntary CSR activities which emphasise on environmental and social issues. Investors believe that CSR is an important factor for business success and many investors equate the CSR performance of companies as a performance measure. Consequently, studies (Eccles, Serafeim, \& Krzus, 2011) are done to understand if the market would be interested in using nonfinancial information, including the disclosure of companies' social and environmental performance, to make investment decisions.

Over the years, the voluntary disclosure of companies' CSR activities has been increasing (Dhaliwal, Li, Tsang, \& Yang, 2014). This 
shows the increased practice of transparency among companies. In the voluntary disclosure literature, many studies (e.g. Jensen \& Meckling, 1976; Healy \& Palepu, 2001) have argued that the agency theory is the main motivation for companies to report on CSR, with a view that companies disclose information to signal their good performance. Yet, there are conflicting findings with regards to the relationship between CSR disclosure and firm value. Some studies (Al-Tuwaijri, Christensen, \& Hughes Ii, 2004; Clarkson, Fang, Li, \& Richardson, 2013; Plumlee, Brown, Hayes, \& Marshall, 2015) indicated a positive relationship between disclosure and firm value. These studies highlighted that CSR was positively received by investors although there were no future cash flows. This indicates that investors believe in companies that are involved with CSR activities. They also perceived these to bring in positive social benefits. There are also studies (Cho, Michelon, Patten, \& Roberts, 2015; Clacher \& Hagendorff, 2012) which observed that disclosure was not in line with firm values and investors do not pay attention to the CSR disclosure. In one experimental test, there was evidence to show that explicit CSR assessments made investors estimate the fundamental firm values to be lower as compared to implicit CSR assessments (Elliott, Jackson, Peecher, \& White, 2014). Other researchers (Kolstad, 2007) noted that CSR activities were viewed as reducing shareholders' welfare to accommodate social purposes.

Since previous research has been inconclusive, further investigation is necessary so as to examine the effect of CSR disclosure on investors' investment decisions. In making a decision, an individual always considers various alternatives and preferences (Bonner, 1999). It is believed that CSR disclosure will give a different corporate value, depending on the effectiveness of the CSR disclosure. The understanding of the effect of CSR disclosure, therefore, is a critical issue. The current research aims to address this gap by experimentally examining the effects of financial information and corporate social responsibility (CSR) disclosure on investment decision. For this purpose, the regulatory focus theory is applied. This study aims to examine the differences of CSR disclosure effect by using two factors - promotion focus and prevention focus, and their effect towards the decision-making process of investors. It also investigates the role of CSR disclosure as a moderator between financial information and investors' decision-making. The current research is conducted using a laboratory experiment focusing on inter-variable causality aspects. 
This research provides three contributions. First, it takes into account the regulatory focus theory for explaining the motivation factors underpinning investors' judgement and decision-making. The regulatory focus theory can predict and explain aspects of the individuals' motivation in achieving their goals by distinguishing between promotion focus (orientation in expectation fulfilment, ideal condition, improvement and advancement) and prevention focus (orientation in obligation fulfilment, responsibility, safety and security), as recommended by Higgins and Cornwell (2016). Individuals with a promotion focus are expected to be more sensitive to the presence or absence of gains; they tend to direct their behaviour towards accomplishment. In contrast, individuals with a prevention focus are expected to be more sensitive to the presence or absence of loss, thus they direct their behaviour towards protection, security and responsibility. While the presence of promotion and prevention focus are indicated in the investment evaluation contexts, there is still a lack of studies that have attempted to tie this theory with CSR and investment decision. Second, this research contributes methodologically by conducting an experimental method to test CSR disclosure. Given the unavailability, quality and reliability of archival CSR data, it is believed that experiments will stand out as a better method to understand the CSR disclosures and their consequences on investors' decision-making (Moser \& Martin, 2012). Third, this research provides practical contributions by providing evidence to highlight how CSR disclosures are related to investors' judgement. Such an understanding offers insights for managerial decisions in determining CSR disclosure strategy as a means to provide maximum benefits for companies.

This paper is structured as follows: Section 2 reviews the literature and hypotheses development. Section 3 explains the research methodology. Section 4 analyses the data, Section 5 discusses the findings and Section 6 concludes.

\section{Literature Review and Hypothesis Development}

\subsection{Corporate Social Responsibility (CSR)}

Corporate social responsibility is a form of voluntary compliance to social obligations. It goes beyond the interests of the company and the legal requirements (McWilliams \& Siegel, 2001). Whilst CSR is voluntary, it has become more prevalent over the years. It appears to be used as a mechanism to motivate stakeholders and to manage societal perceptions about the role of businesses in societies and communities, a 
strategy that goes beyond their core function of producing and selling goods to consumers. The CSR phenomenon is instigated by the upsurge of sensitive consumers who begin demanding for more environmentally friendly products and services, which need to be produced in a sustainable way (Gauthier, 2005; Van Beurden \& Gössling, 2008). This situation then led to the emerging importance of CSR disclosure (Buniamin, Alrazi, Johari, \& Abd. Rahman, 2008). The CSR report contains a great deal of information, such as expenses related to environmental protection and climate change, charity donation and employees' welfare, all of which are typically not reported in the financial statements but which bear significant implications for assessing firm value (Dhaliwal et al., 2011). In a survey of the largest 250 firms worldwide conducted by KPMG in 2017, it was found that 78 per cent of the respondents indicated that they believed that CSR data are useful for investors to make decisions. However, since the CSR disclosure is voluntary, there is no specific rule to follow, thereby resulting in the various forms of information disclosure. To overcome this discrepancy, companies can use the Global Reporting Initiative (GRI) as guidance for international public and private entities that wish to produce sustainability reports. The scope of issues covered by this standard includes economic, environmental, social and governance topics (GRI, 2013).

Within today's environment, rational decision makers need sound information, which not only include financial performance but also nonfinancial performance, including the CSR investment measurements to enable them to make optimal decisions (Hales, Matsumura, Moser, \& Payne, 2016). CSR investment measurements can be divided into costs and benefits (Sprinkle \& Maines, 2010). Measurement of costs for CSR investment will be more accurate and more convenient as compared to the measurement of benefits for CSR investment. Measurement of benefits tends to be unknown and relatively subjective. However, in practice, managers often avoid the disclosure of CSR investment cost. These managers often disclose their CSR activities which benefit other parties because the managers expect a reaction from various parties, including from investors (Martin \& Moser, 2016).

\subsection{Corporate Social Responsibility in Indonesia}

Over the years, the Indonesian government has been continuously introducing numerous laws and regulations. These laws and regulations require companies to engage in certain types of socially responsible behaviour (Rosser \& Edwin, 2010). For example, in 2007, the local 
authority issued a new Limited Company Act known as UU No. 40, which requires any company using natural resources or not directly using natural resources but where their operations have effects on the environment, to undertake social and environmental responsibility activities. Under this regulation, all limited liability companies are obliged to disclose information containing environmental and social responsibility programmes in their annual reports. Another regulation, No. KEP-431/BL/2012, which was established in 2012, also requires that the annual reports of Indonesian publicly listed companies to include their CSR, which should contain labour practices, product responsibilities, social empowerment as well as policies and programmes developed for environmental performance (Ketua Badan Pengawas Pasar Modal dan Lembaga Keuangan, 2012). These annual reports, however, can be disclosed through multiple channels such as annual reports, separate sustainability reports or separate CSR reports (KPMG, 2015). Despite this phenomenon, it appears that the frequent and quality reporting of CSR in Indonesia is still below expectations. This could be due to the ineffective supporting infrastructure for CSR reporting. It also appears that Indonesian companies are not aware of this need to disclose their social activities comprehensively in their annual reports. Apparently, they are still looking at another form of report to accommodate the information of their social activities (Gunawan, 2015).

The practice of CSR has been made mandatory in Indonesia (Rosser \& Edwin, 2010) but it seems that CSR practice could not be disclosed with effectiveness because it is difficult to measure (Fajar, 2018). The implementation of CSR by the Indonesian government is meant to change perceptions of the public towards such companies. It also signals a change of the public's expectations toward how companies should communicate their social and environmental related activities (Yaya, Wibowo, \& Ulfaturrahmah, 2018). Although CSR practice is mandatory, the rules and regulations for implementing it have not been promulgated properly (Herrera, Roman, Alarilla, de Jesus, \& Uy, 2011), and its enforcement mechanism is also weak Even though many companies have been involved in philanthropy or charitable activities, there is still a lack of integration of such initiatives with business strategies (Herrera et al., 2011). Further to this is the weak knowledge and expertise for implementing CSR. All of these have been identified as barriers to the development of CSR in Indonesia (Waagstein, 2011).

Within the literature of CSR practice in Indonesia, there are studies (Famiola \& Adiwoso, 2016; Gunawan, 2015) which have 
highlighted the motivations propelling companies towards CSR implementation. Famiola and Adiwoso (2016) and Gunawan (2015), for example, illustrated that these motivations could be relational, institutional or community based or they could be inspired by shareholders or government pressure. In another study, Hermawan and Mulyawan (2013) found that Indonesian firms embraced CSR as a means to maintain their good reputation, rather than meeting their social responsibility towards community. In another stream of studies, researchers looked into the status of CSR implementation. Herrera et al., (2011) reported that many companies in Indonesia disclosed their CSR activities in the annual report. These companies demonstrated a high commitment towards CSR, both internally and externally, covering the triple bottom line. Likewise, Hidayati (2011) also reported that such companies have gained several benefits in terms of reputation and other competitive advantages. Juniarti's (2018) study illustrated that the development of CSR in Indonesia provided values to long-term shareholders. She argued that implementation of CSR was related to shareholders' value to companies which have low social environmental risks (high-profile companies). This applied to market-based measurements and accounting-based measurements. Smaller companies appear to be reluctant to invest in CSR, possibly because they fear it would negatively affect their corporate financial performance (Fauzi, Mahoney, \& Abdul Rahman, 2007). Nonetheless, companies in Indonesia are less frequent in implementing CSR when compared to multinational companies (MNC) (Fauzi, 2008).

The review of relevant literature (Waagstein, 2011) also highlighted that even though CSR practice is mandatory, there is evidence that CSR disclosure in Indonesia comes in various manifestations, suggesting that there is no uniformity, thereby making the process of evaluating companies' values, difficult. This has made the CSR issues a prime interest among academics. While the studies offered some insights into the status of CSR practices and disclosures as well as motivations behind the move, it seems that there is a lack of study that has attempted to link CSR disclosures with investment decision by using the regulatory focus theory as framework.

\subsection{Regulatory Focus Theory}

Regulatory focus theory (Higgins, 1997; 1998) distinguishes two states of motivation - promotion focus and prevention focus. Individuals incline 
towards the promotion focus tend to have an orientation in expectation fulfilment, ideal condition, improvement and advancement. In contrast, individuals inclined towards the prevention focus have an orientation towards obligation fulfilment, responsibility, safety, and security. Individuals with a promotion focus, think of the gains or non-gains; they will be more sensitive to the presence and absence of positive results. Individuals with a focus on prevention focus think about the loss or nonloss; they will be more sensitive to the presence and absence of negative results. The inter-individual regulatory focus is different, depending on which focus is more sustainable and situational. Regulatory focus theory can be used for understanding the motivational underpinnings of judgment and decision making (Higgins \& Cornwell, 2016).

Regulatory focus can be activated by manipulating the characteristics of the needs associated with promotion focus (achievement needs) and prevention focus (security needs) (Crowe \& Higgins, 1997; Higgins, 2002). Another manipulation that can be used is the default target, which is a situation that leads to ideal conditions being improved for promotion focus and obligations that should be done for prevention focus (Liberman, Molden, Idson, \& Higgins, 2001). Manipulation can be done by framing the message, situation, product attributes, type of decision or instruction, through the consequences of a positive result (for promotion focus) or the consequences of a negative outcome (for prevention focus) (Zhu \& Meyers-Levy, 2007). Regulatory focus theory also states that there are differences in the way (means) the appropriate strategy between promotion focus and prevention focus achieve goals (Cesario, Grant, \& Higgins, 2004; Higgins, 1997; Lieberman, et al., 2001). Individuals inclined towards promotion focus prefer to use eager strategic means to make sure of the presence of positive outcomes and to guard against the absence of positive outcomes. Meanwhile, individuals with prevention focus will prefer to use vigilant strategic means to avoid negative outcomes.

Psychologically, a person's decision is assessed from the perspective of the result value and effort value. The value of a decision is not only related to the final outcomes but also to the appropriate ways of achieving those outcomes. This appropriateness is called 'fit', from a new perspective on decision-making. A common strategy in decisionmaking is stimulating feelings when making certain choices. Based on the regulatory focus theory, one can feel the good and bad things in a different way. With regards to promotion focus, people can feel good about the success of promotions (positive presence or gain) and they 
likewise, feel bad about the failure of promotion (the absence of the positive-non-gain). On the prevention focus, people can feel good about the success of the prevention (the absence of a negative outcome-nonloss) or they can feel bad about the inability to prevent failures (presence of the negative result-loss) (Idson, Liberman, \& Higgins, 2000).

Previous research confirms that individuals adopt a strategy that fits their motivation orientation. Research conducted at the organisational level found that a feeling-right experience that results from a match between an employee and an organisation climate, produces perceptions that the company's prevailing procedures are fair. Past empirical studies have proven that regulatory focus influences individual behaviours in terms of taxation (Holler, Hoelzl, Kirchler, Leder, \& Mannetti, 2008), marketing (Cho, Loibl, \& Geistfeld 2014), firm acquisition (Gamache, Mcnamara, Mannor, \& Johnson, 2015), and innovation decisions (Wallace, Butts, Johnson, Stevens, \& Smith, 2016).

$\mathrm{Gu}$, Bohns, and Leonardelli (2013) applied the regulatory focus theory to predict how individuals achieved both relative and absolute results on the interdependence of decision-making which cannot be explained by traditional theories. They argued that the focus of security (prevention focus) directs attention to the relative yield while the focus of the promotion directs attention to the absolute results. Holler et al. (2008) examined the information campaign to improve tax compliance by using a different framing strategy. Based on this theory, it was deduced that tax compliance campaign will be effective if it was congruent with the receiver's promotion or prevention focus. The highest tax compliance was achieved when there was a regulatory fit. If the receiver's regulatory focus fitted the goal that was framed over the message, the communication process will be more effective because the information was easier to collect (Aaker \& Lee, 2001; Cesario, et al., 2004).

Gamache et al. (2015) investigated whether chief executive officers' (CEOs') regulatory focus impacted the proclivity of firms in undertaking acquisition. It was believed that promotion and prevention foci are important individual differences to consider within organisational settings, particularly when investigating the effects of CEO attributes on firm strategic outcomes. Wallace et al. (2016) tested a multilevel model which examined the effects of employee involvement climate on the individual-level process which linked employee regulatory focus (promotion and prevention) to innovation via thriving. Using data collected at three points from 346 participants who were from 75 groups, the multilevel path analytic results demonstrated support for the 
positive indirect effect of promotion focus to innovation, via thriving, and a negative indirect effect from prevention focus to innovation, via thriving. The results further showed a positive indirect effect from employee involvement climate to innovation, via thriving.

Cho et al. (2014) tested the motivation of saving for emergencies and saving for retirement by using the regulatory focus theory too. They stated that the orientation of promotion and prevention personalities influenced the respondents' financial decision making. Zhou and Pham (2004) predicted differences in financial products which enabled promotion and prevention focus activation. The difference was caused by sensitivity to the potential advantages and disadvantages of the product. The result also demonstrated that investment behaviour was mediated by the difference in promotion and prevention orientations.

Poels and Dewitte (2008) examined behavioural prevention and promotion stimulation which directed the purpose of advertisement. The emotional approach of hope was used in the information presented by the advertisers. Their study attempted to provide insights into the mechanism of hope in influencing behaviour. Hope that comes from a state of dissatisfaction is related to the avoidance of undesired results while hope that comes from satisfying states is related to the achievement of the desired results. Related to the individual's regulatory focus, promotion focus is linked to hope for positive achievement whereas prevention focus is linked to hope for negative resultant avoidance. The study by Poels and Dewitte (2008) found that the advertisement containing prevention focus showed a better result in terms of product information memory and the resulted treatment. This is because individuals with prevention focus were found to be more vigilant and tended to focus on details. Therefore, they were more analytical towards providing information. The outcome generated by Poels and Dewitte (2008) was consistent with what Kim, Kang and Mattilac (2012) found of CSR marketing activities on consumers' behaviour. They noted that consumers were more sensitive to information with a prevention focus because it involved hope for promotion, while information with promotion focus only focussed on the promotion.

In the current research, the individual regulatory focus is situationally triggered by using specific stimulus such as framing, the disclosure of promotion focusses on gain and non-gain, or the disclosure of prevention focus on loss and non-loss. The use of gain and non-gain framing make the goal seemed optimal by emphasising gain over the 
success of desired result achievement. In comparison, loss and nonloss framing make the goal minimal by emphasising on the final goal achievement over the negative absence. The regulatory focus theory is used to examine decisions involving non-financial information, as recommended by Johnson, Smith, Wallace, Hill and Baron (2015). This research responds to the context of investment decisions which are related to CSR information.

\subsection{CSR Disclosure and Investment Decision-Making}

There are many studies which have investigated areas related to CSR (e.g. Al-Tuwaijri et al., 2004; Clarkson et al., 2013; Plumlee et al., 2015). These studies indicated that the disclosure of CSR benefits companies by way of allowing these companies to send a positive signal to investors. The CSR information provided in the annual reports implied that the company was giving a fair treatment to other stakeholders. It also developed a positive outcome on investors who were inclined towards the perception that they would be treated fairly in the future. Plumlee et al. (2015) observed that the quality of environmental responsibility information disclosed actually affected corporate value through cash flow and cost of capital. Similarly, Clarkson et al. (2013) and Griffin and Sun (2013) stated that voluntary environmental disclosures provided additional information about the company's competitiveness and the future company's performance. Both were found to generate a positive return to shareholders. Studies in this area show that the market, including the analyst and investors, reacted positively to the disclosure of CSR. The information on CSR, taken together with the financial information, are both used by investors to facilitate themselves in market valuations. Based on this, the hypothesis is formulated as:

$\mathrm{H}_{1}$ : CSR disclosure influences investment decision-making positively.

\subsection{CSR Disclosure, Focus Regulatory and Investment Decision-Making}

While it appears that CSR disclosure will have a positive impact on investment decision-making (Plumlee et al., 2015; Martin \& Moser, 2016), some studies have noted the negative relationship between these two variables (Beneabou \& Tirole, 2010). For example, Hassel, Nilsson and Nyquist (2005) reported that information disclosing environmental performance tended to be negatively related to the market value of 
equity for Swedish companies. Their findings supported the costconcerned perspective, whereby CSR was seen as a reduction of the shareholders and manager's welfare. In view of the inconsistent results, it is believed that the investors' decision-making is dependent on prevention and promotion goals, as highlighted by the regulatory focus theory. Individuals with a focus on prevention will be more vigilant to the information obtained; they would avoid negative issues with regards to achieving the purpose and they would analyse the information with more details. Furthermore, with the logic that CSR is a negative state due to the sacrifice of profits, the prevention focus is more suitable to the negative avoidance purpose on social and environmental circumstances. Poels and Dewitte (2008) and Kim et al. (2012) found that the role of the advertisement with hopes of prevention was more influential to consumers' behaviour when compared to advertisement with hopes of promotion. In accordance with the context of CSR disclosure, it is claimed that disclosure with the prevention focus would have a greater impact than promotion focus. Based on this, the hypothesis is formulated as:

$\mathrm{H}_{2}$ : An investment decision making based on CSR disclosure with prevention focus is greater than CSR disclosure with promotion focus.

\subsection{Financial Information, CSR Disclosure, Focus Regulatory and Investment Decision-Making}

Even as financial performance disclosure is claimed to be more credible than non-financial performance (Lipe, 1998), other researchers like Maines et al. (2002) stated that the value of financial measures increased when interacting with non-financial measures. The positive and negative tendencies of financial measures affect how analysts pay attention to the non-financial measures (Coram, Mock, \& Monroe, 2011; Ghosh \& $\mathrm{Wu}, 2012)$. It is highlighted that the non-financial performance, such as management quality, innovation, product quality, customers and employees' degree of satisfaction, are only used by analysts when financial information was positive. If the financial information is negative, the non-financial information would not affect the analysts' recommendation. These results are found to be consistent with the prospect theory proposed by Kahneman and Tversky (1979). They mentioned that differences in sensitivity to the gains and losses have different impacts on investors who reacted differently to the positive 
or negative results. Additionally, in making judgments, the negative aspects of a situation tend to be weighted greater than the positive aspects (Kahneman \& Tversky, 1984). In relation to these arguments, it is believed that CSR disclosures can provide effective persuasions for investors to make investment decisions. Individuals' motivation of behaviours can be induced in the information frame of either promotion or prevention focus. Since the focus of loss and non-profit tends to be avoided by individuals who are in the prevention focus, the frame of message or information with a prevention focus will be more effective than information with a promotion frame (Idson et al., 2000).

The current research develops the interaction test of financial and non-financial disclosures in the context of CSR with promotion focus and prevention focus. It is assumed that the relationship of financial information on investors' decision would be moderated by CSR disclosures (with a corresponding focus on promotion and prevention). CSR disclosures with prevention focus would be more influential for the relationship between financial information and investment decision as compared to the CSR disclosure with promotion focus. Based on this, the hypothesis is thus formulated as:

$\mathrm{H}_{3}$ : The CSR disclosure moderates the relationship between financial information and investment decision making. (Specifically: A relationship between financial information and investment decision making will be stronger when CSR disclosures contain prevention focus than when it contains promotion focus).

\section{Research Method}

\subsection{Participants and Experimental Design}

Originally, 60 graduate students participated in this study but due to the fact that 15 did not pass the check on financial information and CSR disclosure manipulation, only 45 graduate students were eligible. Participants are from the Faculty of Economics and Business, Universitas Jenderal Soedirman, Purwokerto, Indonesia. Most are financial practitioners serving in both the public and private sectors. This indicates that they understood the business processes of Indonesia well. As graduate students, the participants can be involved as proxies for non-professional investors with uncomplicated tasks (Elliott, Hodge, Kennedy, \& Pronk, 2007). Graduate students in the role of non- 
professional investors have also been involved in previous research on CSR disclosures (Holm \& Rikhardsson, 2008). Non-professional investors or retailers, from time to time, had been shown to have a significant role to play in the capital markets (Cohen, Holder-Webb, Nath, \& Wood, 2011).

\subsection{Research Variables}

The independent variables used in this research comprise financial information and CSR disclosure. Financial information is manipulated with favourable and unfavourable financial performance. We present a hypothetical company's performance that is derived from the financial statements noted in the Indonesian capital market, which show favourable (positive) and unfavourable (negative) financial performance. The financial performance is based on accounting measures: profitability, return on assets (ROA), return on equity (ROE) and earnings per share (EPS). These measurements are adapted from Lu and Taylor (2015) who separated the measurements based on market and accounting.

The variable, CSR disclosure, is based on the promotion focus and prevention focus perspective, as developed by Poels and Dewitte (2008). The CSR disclosure with a prevention focus describes the disclosure which gave hope to avoid negative occurrences of social and environmental conditions, subsequent to achieving the positive results of the social and environmental conditions. The disclosure with a promotion focus was based on the positive results of the social and environmental conditions.

The dependent variable used in this research is the investment decision. We measure investment decision by using a 10-point Likert scale (Ghosh \& Wu, 2012). In the experiments, we ask participants to decide investment for: sell, hold or buy shares. We give the participants several questions to make sure that they understand the experimental instruments. This research applies a manipulation test with participants rating the financial information and the CSR disclosure. The research instrument is tested through a pilot study involving experts in the field of accounting.

Following the experts' feedback, improvements are made on the financial information and the manipulation check. Feedback from the pilot test is used to fine-tune the wordings on favourable and unfavourable financial information. These are then validated with the 
manipulation of the questions, to see whether the company's financial information is favourable or unfavourable. Improvements are then made accordingly. The manipulation check of the unfavourable financial information, that is, "Is a company's financial information favourable?" is then adjusted. If it is found that the participant's answer lies between a scale of 1 to 4 , it would be assumed that the answer has passed the manipulation check because the participants do not agree. Following this, the CSR disclosure is also fine-tuned.

\subsection{Experimental Procedures}

The experimental instrument is conducted with pencil and paper. All the participants who have agreed to participate are randomly assigned to one of the four experimental conditions. Each participant receives a numbered package for randomisation purposes. Each participant is then informed about his/her role as an investor. They are then asked to follow the experimental steps in sequence, as follows.

\section{Step one}

Participants are given the company's profile and share-ownership information. The company is a chemical company with several business units. The company has branches spread in some areas. Participants have held 30,000 shares for 6 months (Appendix 1).

\section{Step two}

Participants are given a set of activation questions on regulatory focus. Participants with the promotion focus are asked to write their expectations of the social and environmental conditions. Participants with the prevention focus are asked to write their obligations of the social and environmental conditions (Appendix 2).

\section{Step three}

Participants are given the financial information (favourable or unfavourable). Favourable (unfavourable) financial information is indicated by an increase (decrease) in corporate earnings: return on assets (ROA), return on equity (ROE) and earnings per share (EPS). Favourable financial information contains information about the company's financial performance improvement from the previous year. Among others, it includes: profit increase of 16 per cent (1,063.2 billion IDR to $1,349.2$ billion IDR), ROA increases from 5.5 per cent to 6.8 per cent, ROE 
increases from 15 per cent to 17 per cent and EPS increases by 55,000 IDR (208,000 IDR to 263,000 IDR). The favourable financial information given to participants are noted in two columns. The unfavourable financial information shows a declining financial performance over the previous year - a decline in earnings of 1,196.6 billion IDR (-16 per cent). The ROA has decreased from 16.2 per cent to 11.9 per cent, the ROE has decreased from 23.1 per cent to 17.1 per cent, and the EPS has decreased from 937,000 IDR to 762,000 IDR. The unfavourable financial information for participants is provided in cells 3 and 4 (Appendix 3). The favourable financial information shows an increasing profit of 286 billion IDR (16 per cent) from the previous year of 1,063.2 billion IDR. ROA increased to 6.8 per cent as compared to the previous year of 5.5 per cent. ROE increased to 17 per cent as compared to the previous year of 15 per cent. EPS increased to 263,000 IDR compared to 208,000 IDR (Appendix 5).

\section{Step four}

Participants are asked to answer the manipulation test. Participants are asked to rate the company's financial information on a 10-point Likert scale. They would give a high scale (6 to 10) if they consider favourable financial information and a low scale (1-5) if they consider unfavourable financial information. Participants are asked to write their justifications.

\section{Step five}

Participants are given the CSR disclosure. The CSR disclosure with a prevention focus shows the avoidance of negative effects on social and environmental impact but the CSR is beneficial. The CSR disclosure focuses on the benefits received on activities presented, with tables to facilitate investor analysis. The CSR disclosure is presented with a focus on disaster avoidance, reducing unemployment, maintaining health and preventing children from dropping out of schools. The CSR disclosure on avoiding natural disasters contains the planting of 3.3 million trees, reducing of unemployment by providing training and assistance to 865 SMEs with beneficiaries of 3,346 people. The company is responsible for public health by establishing 915 healthcare centres and providing free treatment to 94,223 patients. The company also discloses the prevention of dropout-children by providing scholarships to 2,360 children. Images are presented with negative social and environmental conditions and pictures of positive conditions, after the CSR activities are conducted. The images illustrated a more detailed picture of the social and environmental circumstances. The CSR disclosure with prevention 
focus is noted in cells 2 and 4 (Appendix 4). The CSR disclosure with a promotion focus presented a CSR costs of 2.7 billion IDR incurred by the company, with details of tree planting allocations of 2.7 billion IDR, 8.5 billion IDR for UMKM training, 6.5 billion IDR for scholarships and free medical treatment of 6 billion IDR. The CSR disclosure was presented in an outline but accompanied by a successful image of the CSR programme (Appendix 6).

Step six

Following the above steps, participants are asked to answer the manipulation test. They are asked to rate the CSR disclosure on a 10-point Likert scale. The participants would give a high score (6 to 10) when the company achieves positive results for promotion focus or prevent negative effects on social and environmental conditions for prevention focus. Participants are asked to write their justifications.

\section{Step seven}

Participants then make their investment decisions (sell, hold or buy). The buy decision is shown with a high scale (6-10) and the sell decision is shown with the lowest scale (0-4), while the hold decision is shown on a scale of 5 . The experiment ends with a debriefing to explain the conduct simulations of previous investment decisions.

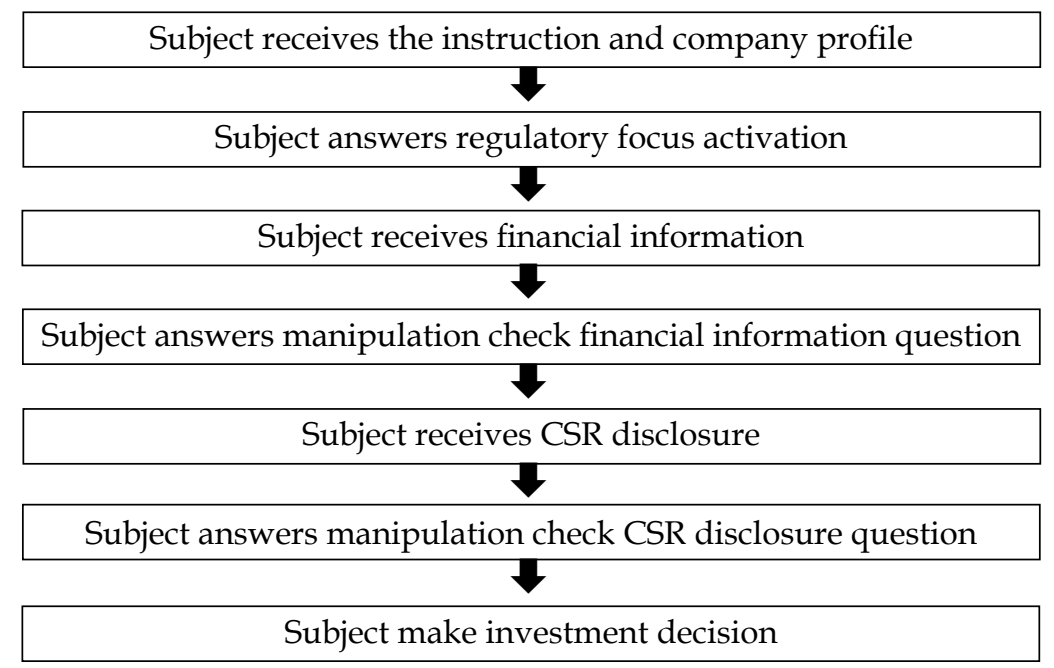

Figure 1: Flow of the Experiment 


\section{Findings}

\subsection{Participants' Demographic Data}

The participants comprise of 21 females and 24 males. The average age of the participants is 30.7 years with an average of 5.8 years of work experience. Participants' demographic profiles are presented in Table 1.

Table 1: Participants' Demographic Data

\begin{tabular}{llcc}
\hline Demographic Profiles & \multicolumn{1}{c}{ Categories } & Frequency & Percentage \\
\hline Gender & Female & 21 & 47.0 \\
& Male & 24 & 53.0 \\
Age & < 25 years old & 6 & 13.3 \\
& 25-30 years old & 15 & 33.3 \\
& >30 years old & 24 & 53.3 \\
Work Experience & <1 year & 6 & 13.3 \\
& 1-10 years & 29 & 64.4 \\
& >10 years & 10 & 22.2 \\
\hline
\end{tabular}

To ensure effective randomisation, one-way ANOVA tests are conducted to ensure that there is no demographic difference in the participants' character (age and gender) within the group. The randomisation results are presented in Table 2.

Table 2: Participants' Randomisation

\begin{tabular}{llrrrrr}
\hline & & $\begin{array}{c}\text { Sum of } \\
\text { Squares }\end{array}$ & Df & Mean & F & Sig \\
\hline Gender & Between Groups & 3.143 & 1 & 3.143 & 0.605 & 0.441 \\
& Within Groups & 223.435 & 43 & 5.196 & & \\
& Total & 226.578 & 44 & & & \\
\multirow{2}{*}{ Age } & Between Groups & 0.004 & 1 & 0.004 & 0.001 & 0.979 \\
& Within Groups & 226.574 & 43 & 5.269 & & \\
& Total & 226.578 & 44 & & & \\
\hline
\end{tabular}

Participants are divided into four (4) groups. The average response of each group is shown in Table 3. The average group with favourable financial information and CSR disclosure with promotion focus is 7 
Table 3: Mean (Standard deviation) Financial Information and CSR Disclosure of Experiment Group

\begin{tabular}{lccccccc}
\hline \multirow{2}{*}{$\begin{array}{l}\text { CSR } \\
\text { Disclosure }\end{array}$} & \multicolumn{4}{c}{ Financial Information } \\
\cline { 2 - 4 } \cline { 7 - 8 } & Mean & Std. Dev. & $\mathrm{n}$ & & Mean & Std. Dev. & $\mathrm{n}$ \\
\cline { 2 - 4 } & 7.00 & 1.00 & 11 & & 3.80 & 1.75 & 10 \\
Promotion & 8.46 & 1.62 & 13 & & 5.64 & 1.57 & 11 \\
\hline
\end{tabular}

$(\mathrm{SD}=1)$, with favourable financial information group response and CSR disclosure with prevention focus is 8.46 (SD = 1.62), with unfavourable financial group response information and CSR disclosure with promotion focus is 3.8 (1.751) and with unfavourable financial information group response and CSR disclosure with prevention focus is $5.64(\mathrm{SD}=1.57)$.

\subsection{Manipulation Test}

Manipulation tests have been done on financial information and CSR disclosures by using a 10-point Likert scale. Participants are considered to have successfully tested the manipulations if they answer on a scale of five (5) for financial information and if they answer below 5-scale for unfavourable information. Participants are considered to have passed the test of CSR disclosure manipulation with the promotion focus and prevention focus when they answer on a scale above five (5). This is further shown in Table 4. The mean score for the group with favourable financial information is 8.33. The mean score for the group with unfavourable financial information is 2.86 . The mean score for the group with CSR disclosure with promotion focus is 8.33 . The mean score for the group with CSR disclosure with prevention focus is 9.13. The manipulation results are also presented in Table 4.

Table 4: Manipulation Test

\begin{tabular}{ccccccc}
\hline & \multicolumn{2}{c}{ Financial Information } & & \multicolumn{2}{c}{ CSR Disclosure } \\
\cline { 2 - 3 } \cline { 6 - 6 } & Favourable & Unfavourable & & Promotion & Prevention \\
\hline Mean & 8.33 & 2.86 & & 8.33 & 9.13 \\
\hline
\end{tabular}




\subsection{Test of Hypotheses}

$\mathrm{H}_{1}$ tests whether CSR disclosure influences investment decisions positively. Results show that CSR disclosure influences the investment decision positively. The ANOVA results confirm the significant effect of CSR disclosure on investment decision. The main effect test shows that information on financial performance and CSR disclosure are significant at $p$ value which is less than 0.01 (Table 5). This indicates that CSR disclosure influences investment decisions positively and supported $\mathrm{H}_{1}$.

Table 5: Main Effects and Interactions Effects Test

\begin{tabular}{|c|c|c|c|c|c|}
\hline & $\begin{array}{l}\text { Type III } \\
\text { SS }\end{array}$ & $\mathrm{DF}$ & $\begin{array}{l}\text { Mean } \\
\text { Square }\end{array}$ & F-Value & Sig. \\
\hline Financial information & 101.195 & 1 & 101.195 & 44.433 & $0.000^{*}$ \\
\hline CSR disclosure & 30.318 & 1 & 30.318 & 13.312 & $0.001^{*}$ \\
\hline $\begin{array}{l}\text { Financial information * } \\
\text { CSR disclosure }\end{array}$ & 0.392 & 1 & 0.392 & 0.172 & 0.681 \\
\hline Error & 93.376 & 41 & 2.277 & & \\
\hline
\end{tabular}

Note: * significant at $1 \%$.

$\mathrm{H}_{2}$ tests the differences in investment decision on the CSR disclosure with promotion focus and prevention focus. We predict that the investment decision will be greater in the CSR disclosure with prevention focus than the CSR disclosure with promotion focus. The test is carried out by using an independent t-test for the CSR disclosure with promotion focus and the CSR disclosure with prevention focus on investment decision. The results are presented in Table 6.

Table 6. Independent t-test

\begin{tabular}{lcccc}
\hline & $\mathrm{n}$ & Mean & Std. Dev. & Independent t-test \\
\hline Financial Information & & & & \\
$\quad$ Favourable & 24 & 7.79 & 1.53 & $\mathrm{~F}=0.225 ; \mathrm{p}=0.000$ \\
$\quad$ Unfavourable & 21 & 4.48 & 1.87 & \\
CSR Disclosure & & & & \\
$\quad$ Promotion Focus & 21 & 5.48 & 2.14 & $\mathrm{~F}=0.423 ; \mathrm{p}=0.011$ \\
Prevention Focus & 24 & 7.17 & 2.12 & \\
\hline
\end{tabular}


It can be seen that the $\mathrm{H}_{2}$ test results show that the mean score of the investment decision making with the CSR disclosure containing prevention focus is 7.17 while the mean score of the investment decision making with the CSR disclosure containing promotion focus is 5.48. The difference is significant at $p$ value which is less than 0.05 . The results of the data thus support $\mathrm{H}_{2}$.

$\mathrm{H}_{3}$ predicts the interaction effect between financial information and CSR disclosure in investment decision. Specifically, the relationship between financial information and investment decision will be stronger when the CSR disclosure carries a prevention focus. The ANOVA result also shows that the results do not support $\mathrm{H}_{3}$. Table 5 illustrates.

\section{Discussions}

The results of this research indicate that financial information and CSR disclosure affect CSR investment decision. The ANOVA results show that the main effect is significant, at 1 per cent. The CSR disclosure results influence investors' decision. This means that management would try to disclose information that is useful for decision makers. The result generated from the current research is consistent with the study conducted by Martin and Moser (2016) who noted that investors react to CSR disclosures. This implies that the CSR information provides additional resources for the investors to make their decision (Clarkson, et al., 2013), and it also shows that the CSR information is useful for investors (Cohen, et al., 2011; Martin \& Moser, 2016). Therefore, the current research has proven that investors not only use financial information in making investment decisions, they also use information sourced from CSR disclosures. Clearly, CSR disclosures emphasise that companies not only sought profit for their welfare but that they are also responsible for the society and environment. The result generated from the current research also shows that CSR disclosures are practised by corporations as a means to enhance themselves. This is because investors are likely to react or respond to CSR disclosures if they are perceived to add value to the corporations. Thus, the current findings support the outcomes provided by Juniarti (2018), which showed that CSR disclosure was positively associated with sustainable shareholder values.

The results of this research also indicate that CSR disclosure with a prevention focus will further lead to greater investments than CSR disclosure with a promotion focus. The t-test results has shown that the group with the CSR information containing a prevention focus has 
an investment decision score of 7.17 while the group with the CSR information containing a promotion focus has an investment decision score of 5.48. Therefore, these results prove that investors would be more affected by the information presented with the prevention focus. These results also reveal that the regulatory focus theory (Higgins, 1997; 1998) can be used to explain the differences in CSR disclosure strategies used for investment decisions. The findings of this research further validate the findings of previous research such as Idson, et al. (2000) who found that in a loss or non-profit state, investors would be sensitive to the prevention focus.

In the context of CSR disclosures, which are related to the company's expenditure on social and environmental activities, it would seem that CSR expenditures would serve as an activity that reduced the welfare of the company and shareholders. Therefore, the CSR information that is framed with a prevention focus would be more effective because it fitted with the individuals' motivation. Investors have the motivation to respect companies that respond to social and environmental aspects. Thus, CSR activities that focus on the prevention of damages done to the social and environmental surroundings would inhibit the negative effect of operations, hence they would illustrate a positive effect for the company, society, and environment. In this way, it can be seen that CSR disclosures with the prevention focus would be presented with more details and more information about the benefits of those CSR activities that have been carried out. Such results are in tandem with Kim, et al. (2012) and Poels and Dewitte (2008) who also observed that with the hope-prevention focus, individuals hoped for positive achievements by preventing negative things. The results of the current research also show that in the case of decision-making, the prevention focus contained in the CSR disclosures is more effective $(\mathrm{Gu}$, et al., 2013). The reason is because the CSR disclosure with prevention focus carries more details, and it emphasises on risk aversions by highlighting the benefits of the CSR activities. Inevitably, this strategy draws more responses from the investors who are more motivated to invest in companies that are involved with CSR activities.

\section{Conclusion and Implications}

This research has experimentally examined the effects of financial information and corporate social responsibility (CSR) disclosure on investment decision. There is evidence to show that CSR disclosure 
affects the investment decision. In addition, the results also show that investment decisions would be greater when the CSR disclosure contains a prevention focus than when it contains a promotion focus. This experimental research also contributes to the regulatory focus theory by providing empirical evidence to support that the CSR disclosure with prevention focus is higher comparatively. This is consistent with the outcomes of Higgins (2002) which stated that the situational aspects of promotion focus differ from prevention focus, in accordance with the behavior to achieve individual goals. The implications drawn for academics suggest that future research needs to use potential future regulatory focus theories to explain and to predict investors' behavior on CSR disclosure.

The implications of this findings for practitioners is that companies need to pay attention to CSR disclosures and how they are presented to investors. It is inevitable for companies to adopt strategies that allow investors to respond to the information positively. The findings of this study further indicate that companies need to disclose CSR activities with a prevention focus and the information should be detailed and should also highlight the benefits provided by the company to the society and the environment. Companies also need to accentuate the enormous cost of the CSR involvement if CSR is not performed accordingly. Although CSR disclosures may have an effect on the financial information and on investment decisions, they are not proven to interact with each other. This result is, therefore not in line with previous studies (e.g. Ghosh \& Wu, 2012).

The implications to be drawn for management is that they need to pay attention to CSR activities and CSR disclosures. Companies should focus not only on making profits but also be concerned about the social and environmental conditions. The results of this research have also indicated that investors are not homogeneous in how they respond to information. Given that investors are sensitive towards negative information, regulators should, thus ensure that sufficient regulations exist so as to prohibit management from failing to disclose negative information to the public. In addition, management and regulators need to consider the investors' goals while designing the disclosure strategies and policies. They should disclose CSR activities and they can adopt disclosure strategies by adopting the prevention focus which avoids negative social and environmental aspects of the company's activities. Companies that have CSR disclosure would have more investors' responding to such information when making investment decisions. 
This research is, nonetheless, also limited in some ways. First this research does not distinguish explicitly whether CSR performance is favourable or unfavourable. Instead, it used the reason that CSR disclosure is an activity that shows a reduction in manager and shareholders' welfare. Therefore, future research needs to focus on examining favourable or unfavourable CSR performance, with more comprehensive promotion and prevention frames.

This research only examines the situational effects on the regulatory focus. It does not examine the chronic effects on individual's regulatory focus. Future research is expected to implement both the chronic and situational effects on individual's regulatory focus for decision making (Idson, et al., 2000). Furthermore, this research applies the explicit assessment of CSR disclosure in making decisions which could produce different results if the participants have not conducted an assessment (Elliott et al., 2014). Therefore, future research may consider the individual's affective reactions to investment decisions.

\section{References}

Aaker, J.L., \& Lee, A.Y. (2001). "I" seek pleasures and "we" avoid pains: The role of self-regulatory goals in information processing and persuasion. Journal of Consumer Research, 28(1), 33-49. http://dx.doi.org/10.1086/321946

Al-Tuwaijri, S.A., Christensen, T.E., \& Hughes Ii, K.E. (2004). The relations among environmental disclosure, environmental performance, and economic performance: A simultaneous equations approach. Accounting, Organizations and Society, 29(5-6), 447-471. http://dx.doi.org/10.1016/ S0361-3682(03)00032-1

Bénabou, R., \& Tirole, J. (2010). Individual and corporate social responsibility. Economica, 77(305), 1-19. http://dx.doi.org/10.1111/j.1468-0335.2009. 00843.x

Bonner, S.E. (1999). Judgment and decision-making research in accounting. Accounting Horizons, 13(4), 385-398. http://dx.doi.org/10.2308/acch.1999. 13.4.385

Buniamin, S., Alrazi, B., Johari, N.H., \& Abd. Rahman, N.R. (2008). An investigation of the association between corporate governance and environmental reporting in Malaysia. Asian Journal of Business and Accounting, 1(2), 65-88.

Cesario, J., Grant, H., \& Higgins, E.T. (2004). Regulatory fit and persuasion: Transfer from "feeling right". Journal of Personality and Social Psychology, 86(3), 388-404. http://dx.doi.org/10.1037/0022-3514.86.3.388

Cho, C.H., Michelon, G., Patten, D.M., \& Roberts, R.W. (2015). CSR disclosure: The more things change...? Accounting, Auditing \& Accountability Journal, 28(1), 14-35. http://dx.doi.org/10.1108/AAAJ-12-2013-1549 
Cho, S.H., Loibl, C., \& Geistfeld, L. (2014). Motivation for emergency and retirement saving: An examination of regulatory focus theory. International Journal of Consumer Studies, 38(6), 701-711. http:/ / dx.doi.org/10.1111/ijcs.12143

Clacher, I., \& Hagendorff, J. (2012). Do announcements about corporate social responsibility create or destroy shareholder wealth? Evidence from the UK. Journal of Business Ethics, 106(3), 253-266. http://dx.doi.org/10.1007/ s10551-011-1004-9

Clarkson, P.M., Fang, X., Li, Y., \& Richardson, G. (2013). The relevance of environmental disclosures: Are such disclosures incrementally informative? Journal of Accounting and Public Policy, 32(5), 410-431. http://dx.doi.org/ 10.1016/j.jaccpubpol.2013.06.008

Cohen, J., Holder-Webb, L., Nath, L., \& Wood, D. (2011). Retail investors' perceptions of the decision-usefulness of economic performance, governance, and corporate social responsibility disclosures. Behavioral Research in Accounting, 23(1), 109-129. http:/ / dx.doi.org/10.2308/bria.2011.23.1.109

Coram, P.J., Mock, T.J., \& Monroe, G.S. (2011). Financial analysts' evaluation of enhanced disclosure of non-financial performance indicators. The British Accounting Review, 43(2), 87-101. http://dx.doi.org/10.1016/j.bar.2011. 02.001

Crowe, E., \& Higgins, E.T. (1997). Regulatory focus and strategic inclinations: Promotion and prevention in decision-making. Organizational Behavior and Human Decision Processes, 69(2), 117-132. http://dx.doi.org/10.1006/ obhd.1996.2675

Dhaliwal, D., Li, O.Z., Tsang, A., \& Yang, Y.G. (2014). Corporate social responsibility disclosure and the cost of equity capital: The roles of stakeholder orientation and financial transparency. Journal of Accounting and Public Policy, 33(4), 328-355. http:/ / dx.doi.org/10.1016/j.jaccpubpol.2014.04.006

Dhaliwal, D.S., Li, O.Z., Tsang, A., \& Yang, Y.G. (2011). Voluntary nonfinancial disclosure and the cost of equity capital: The initiation of corporate social responsibility reporting. The Accounting Review, 86(1), 59-100. http://dx. doi.org/10.2308/accr.00000005

Eccles, R.G., Serafeim, G., \& Krzus, M.P. (2011). Market interest in nonfinancial information. Journal of Applied Corporate Finance, 23(4), 113-127. http://dx. doi.org/10.1111/j.1745-6622.2011.00357.x

Elliott, W.B., Hodge, F.D., Kennedy, J.J., \& Pronk, M. (2007). Are MBA students a good proxy for nonprofessional investors? The Accounting Review, 82(1), 139-168. http:/ / dx.doi.org/10.2308/accr.2007.82.1.139

Elliott, W.B., Jackson, K.E., Peecher, M.E., \& White, B.J. (2014). The unintended effect of corporate social responsibility performance on investors' estimates of fundamental value. The Accounting Review, 89(1), 275-302. http:/ / dx.doi. org/10.2308/accr-50577

Fajar, M. (2018). Corporate Social Responsibility in Indonesia: Regulation and Implementation Issues. Journal of Legal, Ethical and Regulatory Issues, 21(3), 1-12. 
Famiola, M., \& Adiwoso, S.A. (2016). Corporate social responsibility diffusion by multinational subsidiaries in Indonesia: Organisational dynamic and institutional effect. Social Responsibility Journal, 12(1), 117-129. http://dx. doi.org/10.1108/SRJ-10-2013-0128

Fauzi, H. (2008). Corporate social and environmental performance: A comparative study of Indonesian companies and multinational companies (MNCs) operating in Indonesia. Journal of Knowledge Globalization, 1(1), 81-105.

Fauzi, H., Mahoney, L.S., \& Abdul Rahman, A. (2007). The link between corporate social performance and financial performance: Evidence from Indonesian companies. Issues in Social and Environmental Accounting, 1(1), 149-159.

Gamache, D.L., McNamara, G., Mannor, M.J., \& Johnson, R.E. (2015). Motivated to acquire? The impact of CEO regulatory focus on firm acquisitions. Academy of Management Journal, 58(4), 1261-1282. http://dx.doi.org/ 10.5465/amj.2013.0377

Gauthier, C. (2005). Measuring corporate social and environmental performance: The extended life-cycle assessment. Journal of Business Ethics, 59(1-2), 199206. http://dx.doi.org/10.1007/s10551-005-3416-x

Ghosh, D., \& Wu, A. (2012). The effect of positive and negative financial and nonfinancial performance measures on analysts' recommendations. Behavioral Research in Accounting, 24(2), 47-64. http://dx.doi.org/10.2308/ bria-10283

GRI. (2013). Sustainability reporting guidelines. Amsterdam: Global Reporting Initiatives.

Griffin, P.A., \& Sun, Y. (2013). Going green: Market reaction to CSRwire news releases. Journal of Accounting and Public Policy, 32(2), 93-113. http://dx.doi. org/10.1016/j.jaccpubpol.2013.02.002

$\mathrm{Gu}$, J., Bohns, V.K., \& Leonardelli, G.J. (2013). Regulatory focus and interdependent economic decision-making. Journal of Experimental Social Psychology, 49(4), 692-698. http://dx.doi.org/10.1016/j.jesp.2012.11.008

Gunawan, J. (2015). Corporate social disclosures in Indonesia: Stakeholders' influence and motivation. Social Responsibility Journal, 11(3), 535-552. http://dx.doi.org/10.1108/SRJ-04-2014-0048

Hales, J., Matsumura, E.M., Moser, D.V., \& Payne, R. (2016). Becoming sustainable: A rational decision based on sound information and effective processes? Journal of Management Accounting Research, 28(2), 13-28. http:// dx.doi.org/10.2308/jmar-51394

Hassel, L., Nilsson, H., \& Nyquist, S. (2005). The value relevance of environmental performance. European Accounting Review, 14(1), 41-61. http://dx.doi. org/10.1080/0963818042000279722

Healy, P.M., \& Palepu, K.G. (2001). Information asymmetry, corporate disclosure, and the capital markets: A review of the empirical disclosure literature. Journal of Accounting and Economics, 31(1-3), 405-440. http:// dx.doi.org/10.1016/S0165-4101(01)00018-0 
Hermawan, M., \& Mulyawan, S. (2013). Profitability and corporate social responsibility: An analysis of Indonesia's listed company. Asia Pacific Journal of Accounting and Finance, 3(15-31).

Herrera, M.E., Roman, F.L., Alarilla, M.C., de Jesus, M.K., \& Uy, R.V. (2011). Corporate social responsibility in Southeast Asia: An eight country analysis. Manila: Ramon V. del Rosario Sr. Centre for Corporate Social Responsibility, Asian Institute of Management.

Hidayati, N.D. (2011). Pattern of corporate social responsibility programs: A case study. Social Responsibility Journal, 7(1), 104-117. http://dx.doi.org/ 10.1108/17471111111114576

Higgins, E.T. (1997). Beyond pleasure and pain. American Psychologist, 52(12), 1280-1300. http://dx.doi.org/10.1037/0003-066X.52.12.1280

Higgins, E.T. (1998). Promotion and prevention: Regulatory focus as a motivational principle. Advances in Experimental Social Psychology, 30, 1-46. http:/ / dx.doi.org/10.1016/S0065-2601(08)60381-0

Higgins, E.T. (2002). How self-regulation creates distinct values: The case of promotion and prevention decision making. Journal of Consumer Psychology, 12(3), 177-191. http://dx.doi.org/10.1207/S15327663JCP1203_01

Higgins, E.T., \& Cornwell, J.F.M. (2016). Securing foundations and advancing frontiers: Prevention and promotion effects on judgment \& decision making. Organizational Behavior and Human Decision Processes, 136(September), 56-67. http://dx.doi.org/10.1016/j.obhdp.2016.04.005

Holler, M., Hoelzl, E., Kirchler, E., Leder, S., \& Mannetti, L. (2008). Framing of information on the use of public finances, regulatory fit of recipients and tax compliance. Journal of Economic Psychology, 29(4), 597-611. http://dx. doi.org/10.1016/j.joep.2008.01.001

Holm, C., \& Rikhardsson, P. (2008). Experienced and novice investors: Does environmental information influence investment allocation decisions? European Accounting Review, 17(3), 537-557. http://dx.doi.org/10.1080/ 09638180802016627

Idson, L.C., Liberman, N., \& Higgins, E.T. (2000). Distinguishing gains from nonlosses and losses from nongains: A regulatory focus perspective on hedonic intensity. Journal of Experimental Social Psychology, 36(3), 252-274. http://dx.doi.org/10.1006/jesp.1999.1402

Jensen, M.C., \& Meckling, W.H. (1976). Theory of the firm: Managerial behavior, agency costs and ownership structure. Journal of Financial Economics, 3(4), 305-360. http:/ / dx.doi.org/10.1016/0304-405X(76)90026-X

Johnson, P.D., Smith, M.B., Wallace, J.C., Hill, A.D., \& Baron, R.A. (2015). A review of multilevel regulatory focus in organizations. Journal of Management, 41(5), 1501-1529. http://dx.doi.org/10.1177/01492063155 75552

Juniarti. (2018). Exploring the sustainable shareholder value of corporate social responsibility activities. International Journal of Management and Applied Research, 5(2), 42-54. http://dx.doi.org/10.18646/2056.52.18-004 
Kahneman, D., \& Tversky, A. (1979). Prospect theory: An analysis of decision under risk. Econometrica, 47(2), 263-292.

Kahneman, D., \& Tversky, A. (1984). Choice, values, and frames. American Psychologist, 39(4), 341-350.

Ketua Badan Pengawas Pasar Modal dan Lembaga Keuangan. (2012). Laporan tahunan emiten atau perusahaan publik. Retrieved from https://www.ojk. go.id/Files/regulasi/pasar-modal/bapepam-pm/emiten-pp/pelaporan/X.K.6.pdf

Kim, E.E.K., Kang, J., \& Mattilac, A.S. (2012). The impact of prevention versus promotion hope on CSR activities. International Journal of Hospitality Management, 31(1), 43-51. http:/ / dx.doi.org/10.1016/j.ijhm.2011.05.004

Kolstad, I. (2007). Why firms should not always maximize profits. Journal of Business Ethics, 76(2), 137-145. http:/ / dx.doi.org/10.1007/s10551-006-9262-7

KPMG. (2015). The KPMG survey of corporate responsibility reporting 2015. The Netherlands: Author.

Liberman, N., Molden, D.C., Idson, L.C., \& Higgins, E.T. (2001). Promotion and prevention focus on alternative hypotheses: Implications for attributional functions. Journal of Personality and Social Psychology, 80(1), 5-18. http:/ /dx. doi.org/10.1037/0022-3514.80.1.5

Lipe, M.G. (1998). Individual investors' risk judgments and investment decisions: The impact of accounting and market data. Accounting, Organizations and Society, 23(7), 625-640. http:/ /dx.doi.org/10.1016/S03613682(97)00065-2

Lu, W., \& Taylor, M.E. (2015). Which factors moderate the relationship between sustainability performance and financial performance? A meta-analysis study. Journal of International Accounting Research, 15(1), 1-15. http:/ / dx.doi. org/10.2308/jiar-51103

Maines, L.A., Bartov, E., Fairfield, P.M., Hirst, D.E., Iannaconi, T.E., Mallett, R., ... \& Vincent, L. (2002). Recommendations on disclosure of nonfinancial performance measures. Accounting Horizons, 16(4), 353-362. http://dx.doi. org/10.2308/acch.2002.16.4.353

Martin, P.R., \& Moser, D.V. (2016). Managers' green investment disclosures and investors' reaction. Journal of Accounting and Economics, 61(1), 239-254. http://dx.doi.org/10.1016/j.jacceco.2015.08.004

McWilliams, A., \& Siegel, D. (2001). Corporate social responsibility: A theory of the firm perspective. Academy of Management Review, 27 (1), 117-127. http:/ /dx.doi.org/10.5465/amr.2001.4011987

Moser, D.V., \& Martin, P.R. (2012). A broader perspective on corporate social responsibility research in accounting. The Accounting Review, 87(3), 797-806. http:/ /dx.doi.org/10.2308/accr-10257

Plumlee, M., Brown, D., Hayes, R.M., \& Marshall, R.S. (2015). Voluntary environmental disclosure quality and firm value: Further evidence. Journal of Accounting and Public Policy, 34(4), 336-361. http://dx.doi.org/10.1016/j. jaccpubpol.2015.04.004 
Poels, K., \& Dewitte, S. (2008). Hope and self-regulatory goals applied to an advertising context: Promoting prevention stimulates goal-directed behavior. Journal of Business Research, 61(10), 1030-1040. http://dx.doi. org/10.1016/j.jbusres.2007.09.019

Rosser, A., \& Edwin, D. (2010). The politics of corporate social responsibility in Indonesia. The Pacific Review, 23(1), 1-22. http://dx.doi. org/10.1080/09512740903398314

Sprinkle, G.B., \& Maines, L.A. (2010). The benefits and costs of corporate social responsibility. Business Horizons, 53(5), 445-453. http://dx.doi.org/ 10.1016/j.bushor.2010.05.006

Van Beurden, P., \& Gössling, T. (2008). The worth of values: - A literature review on the relation between corporate social and financial performance. Journal of Business Ethics, 82(2), 407-424. http://dx.doi.org/10.1007/s10551008-9894-x

Waagstein, P.R. (2011). The mandatory corporate social responsibility in Indonesia: Problems and implications. Journal of Business Ethics, 98(3), 455-466. http://dx.doi.org/10.1007/s10551-010-0587-x

Wallace, J.C., Butts, M.M., Johnson, P.D., Stevens, F.G., \& Smith, M.B. (2016). A multilevel model of employee innovation: Understanding the effects of regulatory focus, thriving, and employee involvement climate. Journal of Management, 42(4), 982-1004. http:/ /dx.doi.org/10.1177/0149206313506462

Yaya, R., Wibowo, S.A., Ulfaturrahmah, \& Jalaludin, D. (2018). Environmental disclosure practices after mandatory disclosure policy in Indonesia. Journal of Business and Retail Management Research, 12(4), 88-100.

Zhou, R., \& Pham, M.T. (2004). Promotion and prevention across mental accounts: When financial products dictate consumers \& investment goals. Journal of Consumer Research, 31(1), 125-135. http://dx.doi. org/10.1086/383429

Zhu, R., \& Meyers-Levy, J. (2007). Exploring the cognitive mechanism that underlies regulatory focus effects. Journal of Consumer Research, 34(1), 89-96. http://dx.doi.org/10.1086/513049 


\section{Appendix 1. Company Profile, Role and Task}

\section{Company Profile}

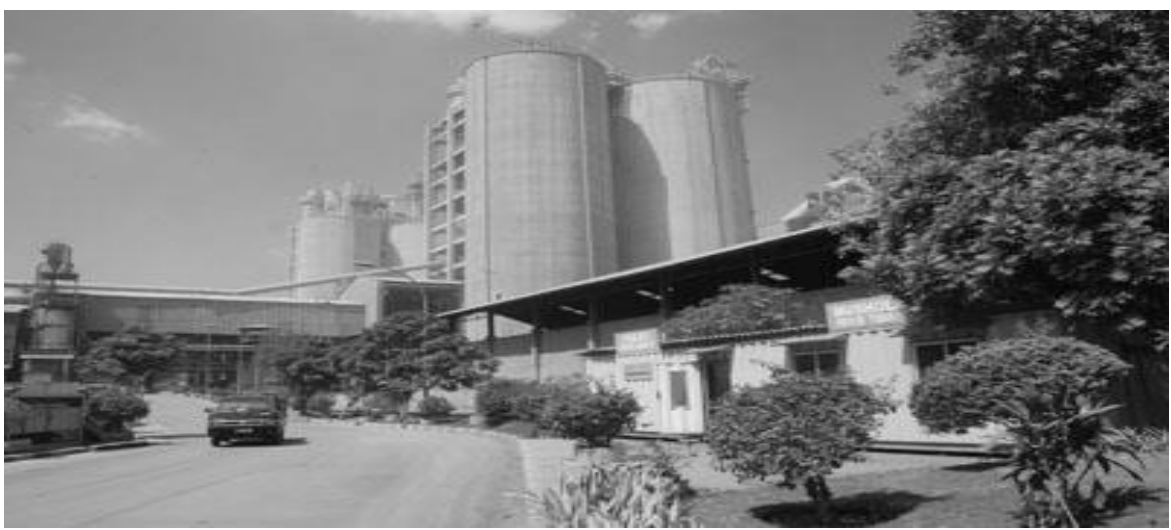

PT. Medico Jaya is a pharmaceutical company with the deed of establishment No. 17 on 2nd February 2001 at the notary of Jakarta and has been approved by the Minister of Justice of the Indonesian Republic. The company produces medicines that are nationally distributed. By 2015, the company already has 21,356 employees at 62 branch companies across Indonesia.

Role

Your role is investor in PT. Medico Jaya with ownership of 30,000 shares. You have owned since six (6) months ago. The value of each share is 6,000.00 IDR.

\section{Task}

You have to make an investment decision

- buy additional shares (BUY)

- retain owned shares (HOLD)

- sell shares that have been owned (SELL)

\section{Appendix 2. Focus Regulatory Activation (Prevention Focus CSR)}

Write your obligations on social and environmental conditions:

1.

2.

3. 


\section{Appendix 3. Manipulation Unfavourable Financial Information}

In 2015 the company experienced a decrease in earnings of 1,196.7 billion IDR $(16 \%)$. Return on Assets (ROA) decreased to $11.9 \%$ compared with the previous year of $16.2 \%$. Return on Equity (ROE) decreased to $17.1 \%$, compared with $23.1 \%$ in the previous year. Earnings per share (EPS) decreased to 762,000 IDR compared to the previous year of 937,000 IDR. Financial performance is presented as follows (Figure A3.1):
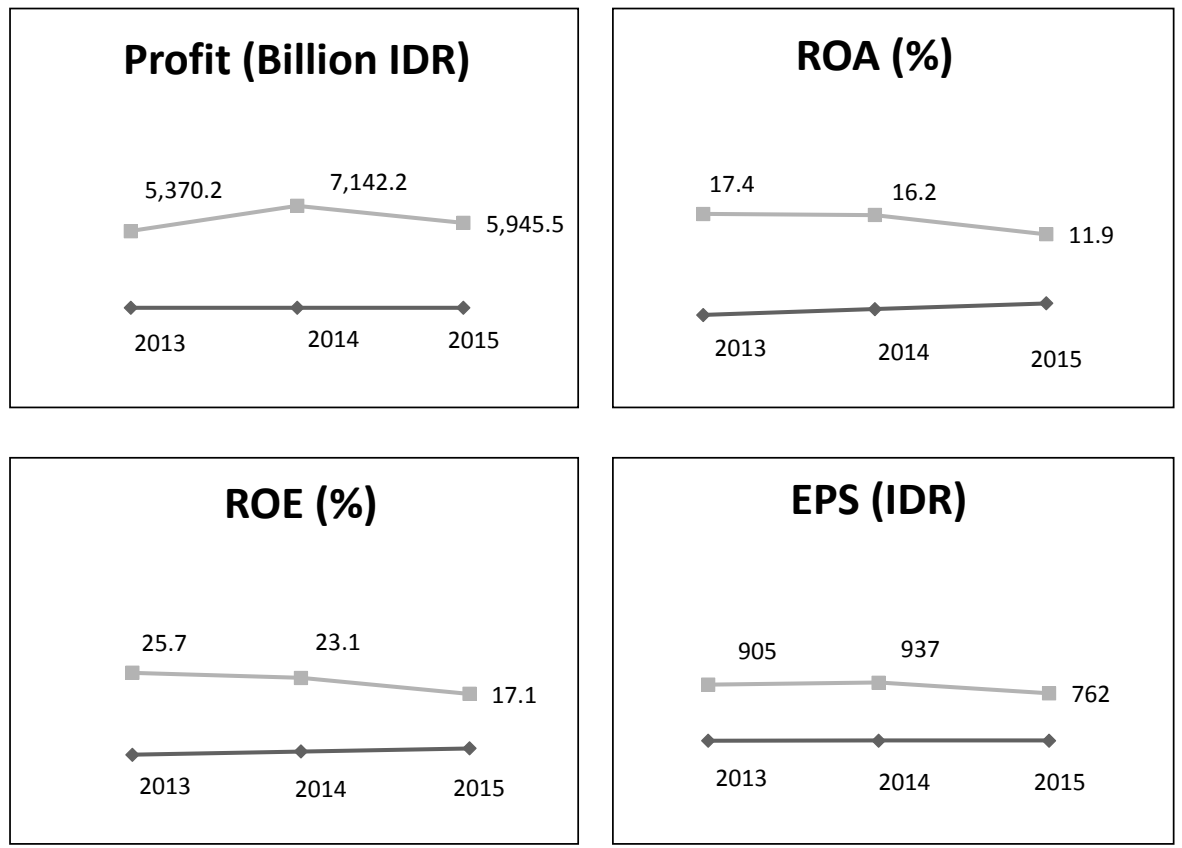

Figure A3.1: Financial Information Manipulation Check

The company has favourable financial performance in 2015.

\begin{tabular}{|l|c|c|c|c|c|c|c|c|c|}
\hline 1 & 2 & 3 & 4 & 5 & 6 & 7 & 8 & 9 & 10 \\
\hline \\
Strongly Disagree \\
Strongly Agree \\
\hline
\end{tabular}

Please explain your reason: 


\section{Appendix 4. Manipulation CSR Disclosure - Prevention Focus}

PT. Medico Jaya participates in sustainable development through social responsibility activities by contributing significantly to improving the quality of life of Indonesians. PT. Medico Jaya is committed to providing added value to the progress of Indonesians in the fields of education, environmental conservation, health services and the development of small and medium enterprises (SMEs) that support the economic income of the wider community. The company has provided benefits to the community by issuing CSR funds of 23.7 billion IDR. This value increased from the previous year's expenditure of 18.4 billion IDR.

In addition to the funds allocated for social and environmental, in business processes, companies pay attention to the safety of their employees, conduct environmentally friendly business processes and manage waste well so avoid pollution. As a form of company's seriousness on social responsibility activities, the company has been awarded by the government for the implementation of corporate social responsibility (CSR). This award can enhance the company's reputation as a good company.
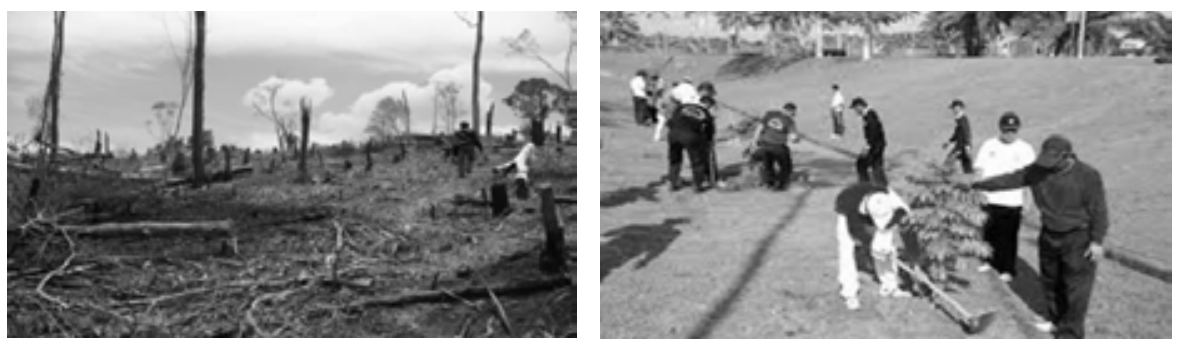

Note: PT. Medico Jaya participates to avoid natural disasters and environmental pollution by realising tree planting programs to achieve environmental conservation. PT. Medico Jaya has planted more than 3.3 million trees.
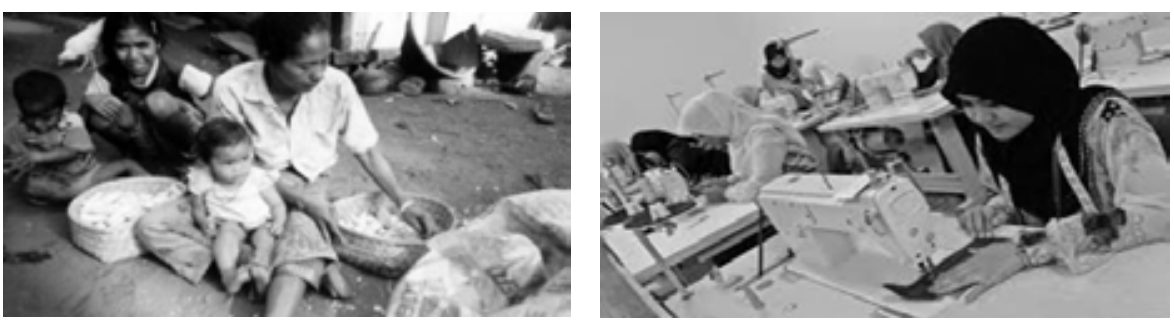

Note: PT. Medico Jaya participates to reduce the number of unemployed with training and assistance for the community. PT. Medico Jaya provides training and capital assistance to 865 SMEs with 32,346 beneficiaries. 

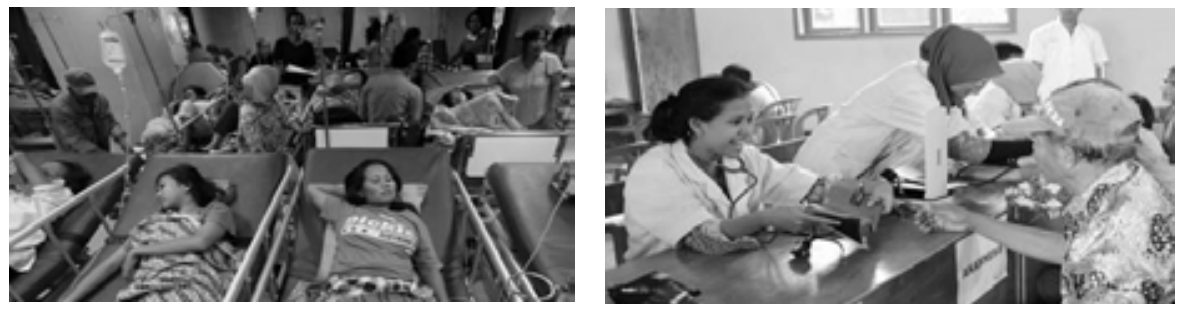

PT. Medico Jaya is obliged to help maintain public health. PT. Medico Jaya founded 915 health care establishments and provided free treatment to 94,223 patients.
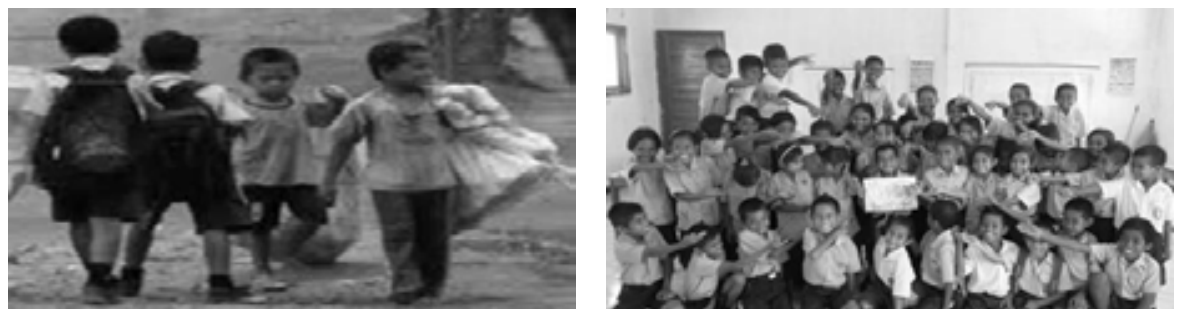

Company participate in preventing children from dropping out, by providing scholarships. PT. Medico Jaya provides scholarships to 2,360 children so they can continue their education.

\section{Manipulation Check of CSR Disclosure-Prevention Focus}

The company has prevented negative effect of social and environment.

\begin{tabular}{|c|c|c|c|c|c|c|c|c|c|}
\hline 1 & 2 & 3 & 4 & 5 & 6 & 7 & 8 & 9 & 10 \\
\hline \multicolumn{8}{|c|}{ Strongly Disagree } & \multicolumn{2}{|c|}{ Strongly Agree } \\
\hline
\end{tabular}

Please explain your reason:

Based on the available information, please make investment decision:

\begin{tabular}{|l|l|l|l|l|l|l|l|l|l|}
\hline 1 & 2 & 3 & 4 & 5 & 6 & 7 & 8 & 9 & 10 \\
\hline Sell & Bold \\
\hline
\end{tabular}




\section{Appendix 5. Manipulation Favourable Financial Information}

In 2015, the company achieved a profit of 1,349.2 billion IDR; this shows an increase in profit of 286 billion IDR (16\%) from the previous year's 1,063.2 billion IDR. Return on assets (ROA) increased to $6.8 \%$ compared to the previous year's $5.5 \%$. Return on equity (ROE) increased to $17 \%$, compared to the previous year's $15 \%$. Earnings per share (EPS) increased to 263,000 IDR compared to the previous year's amount of 208,000 IDR. Financial performance is presented as follows:
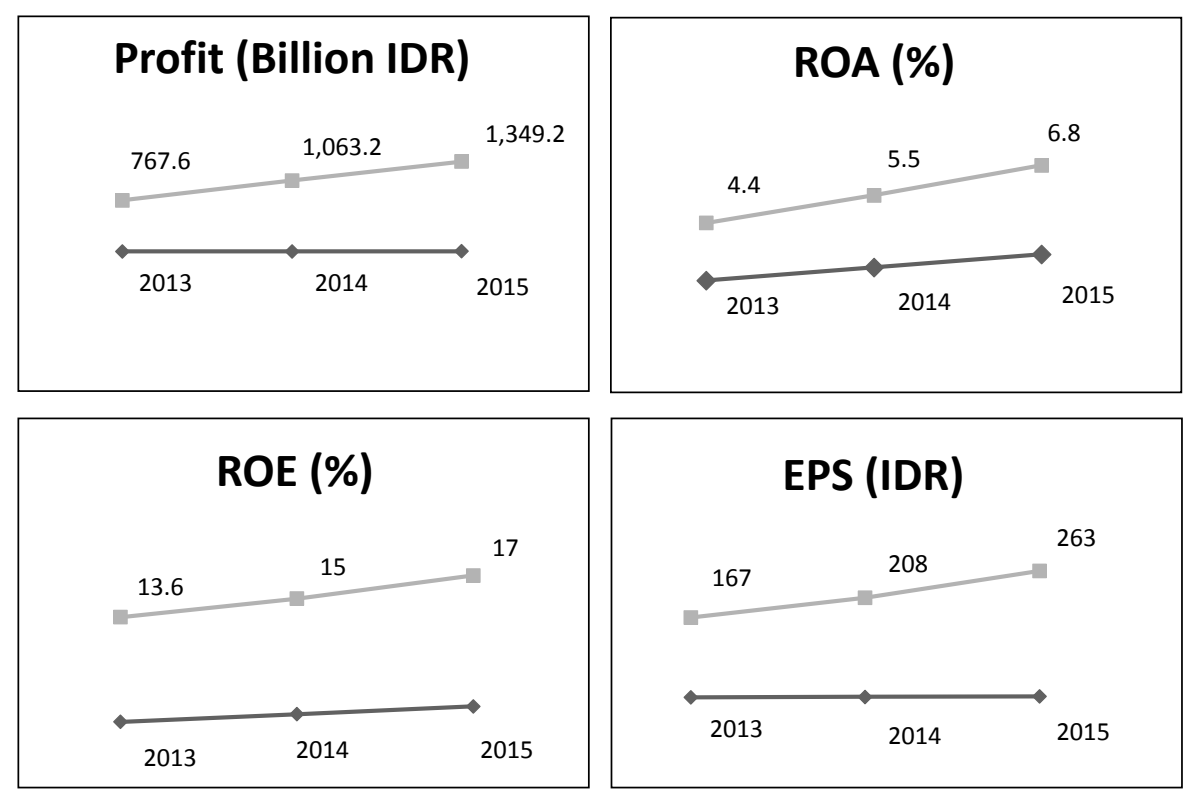

Figure A5.1: Financial Information Manipulation Check

The company has favourable financial performance in 2015.

\begin{tabular}{|l|c|c|c|c|c|c|c|c|c|}
\hline 1 & 2 & 3 & 4 & 5 & 6 & 7 & 8 & 9 & 10 \\
\hline \\
Strongly Disagree \\
\multicolumn{10}{|l|}{ Strongly Agree } \\
\hline
\end{tabular}

Please explain your reason: 


\section{Appendix 6. Manipulation CSR Disclosure - Promotion Focus}

The company supports sustainable community development efforts through a variety of social assistance initiatives and programs covering the environment, health, SME empowerment and education. The environmental development program is intended to improve the social conditions around the company and other areas that need it. The company identifies the needs of each region in the implementation of the environmental development program. Total funding for CSR activities is 23.7 billion IDR.

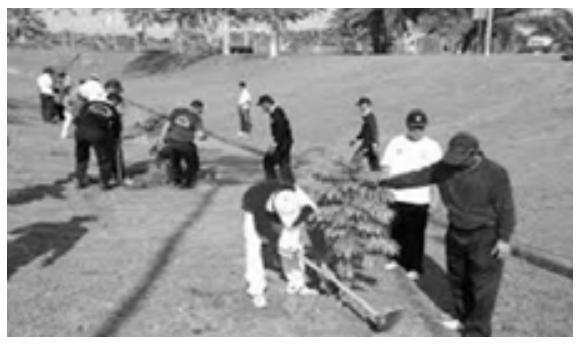

PT. Medico Jaya allocated 2.7 billion IDR for tree planting

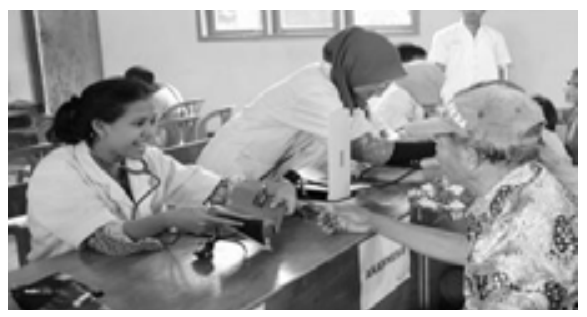

PT Medico Jaya provides free treatment of 6 billion IDR

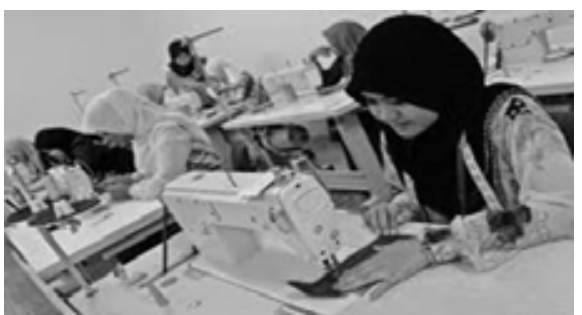

PT Medico Jaya conducts training and assistance for SMEs with a total cost of 8.5 billion IDR

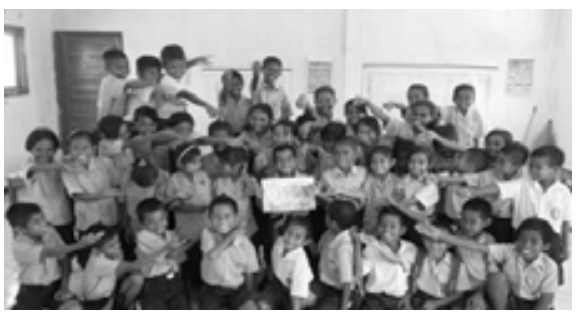

PT Medico Jaya provides a scholarship of 6.5 billion IDR

\section{Manipulation Check of CSR Disclosure-Promotion Focus}

The company has achieved positive results on social and environmental conditions through CSR activities.

\begin{tabular}{|l|c|c|c|c|c|c|c|c|c|}
\hline 1 & 2 & 3 & 4 & 5 & 6 & 7 & 8 & 9 & 10 \\
\hline Strongly Disagree & Strongly Agree \\
\hline
\end{tabular}


Please explain your reason:

Based on the available information, please make investment decision:

\begin{tabular}{|c|c|c|c|c|c|c|c|c|c|}
\hline 1 & 2 & 3 & 4 & 5 & 6 & 7 & 8 & 9 & 10 \\
\hline Sell & Hold \\
\hline
\end{tabular}

